\title{
A SKETCH OF THE SANITARY HISTORY OF NEWCASTLE-UPON-TYNE,
}

being a continuation of a paper read by Dr. H. E. Armstrong at the Congress of the Institute in 1882,

I3y J. COOTE HIBBERT, M.D., D.P.F., (IEMBER),

And W. H. WELLS,

Sanitary Inspector.

Read at Sessional Meeting, Newcastle-upon-Tyne, March 15th, 1907.

\section{Dr. J. COOTE HIBBERT.}

TN the year 1882, at a Congress of The Sanitary Institute in this city, Dr. Armstrong read a paper on the Sanitary History of Newcastle-upon-Tyne up to that date. In that paper, despite the greater part of the period then dealt with being practically prehistoric so far as hygienic records went, despite the alsence or dimness of those scientitic searchlights which at the present day enable us to see more deeply into the mystery of disease, there was laid before this association a graphic description of those former times of plague and pestilence. The circumstances attending the birth of this historic city, the many vicissitudes through which it passed during its early years, and the influence which those early years still exerted on the more recent times, the city's embryonic attempts at sanitation and its first efforts to grapple with those devastating epidemics of infectious disease, which in one year carried off even a third of its total population-all these details were passed in review, and a typical picture of those dark ages of sanitation was presented. During the decade, however, which began with 1873, in which year the Newcastle Sanitary Authority first appointed a melical officer of health, the dawn of the modern sanitary era appeared, and at the end of those ten years, a reduction of the yearly death-rate by 10 per 1,000 of the population, and a diminution of typhus fever to a fifth of its prevalence 


\section{A Sketch of the Sanitary History of Newcastle-upon-Tyne.}

in the years immediately antecedent to that period, were the first happy augury of better times.

To Mr. Wells and myself has been entrusted the task of continuing this Sanitary History of Newcastle to the present time. For the honour of reading this paper, I am indebted to Dr. Armstrong, from whose thirtythree anmual and numerous special reports I have abstracted the facts herein related.

During the last quarter of a century the population of Newcastle has increased from 147,626 in 1882 to an estimated 272,969 for the present year. Towards the end of 1904 the districts of Walker, Benwell, and Fenham, and part of Kenton, with a population of 35,276 , and an area of about 3,000 acres, were incorporated within the city boundaries, which now comprise about 8,460 incres.

The general death-rate, which during the five yoars $1883-87$ averaged $24 \cdot 5$ per 1,000 population, has fallen to an average of $19 \cdot 1$ during the five years 1901-05, and to $18 \cdot 0$ last year. Newcastle presents no exception to the general rule of a diminishing lirth-rate, the averages being 38.6 and 31.7 per 1,000 population for the two quinquennial periods, and the marriage-rate per 1,000 population shows the same clownward trend, with the figures $11 \cdot 6$ and $9 \cdot 4$ respectively for the periods before mentioned.

In no way perhaps has sanitation conferred greater benefits on mankind than in its influence on the prevalence and severity of the infectious diseases, and, fortunately, I am able to give the extent of the chief of these diseases in the city during the years under consideration, as the Newcastle Improvement Act of 1882 contained certain clauses unaling their notification compulsory. It is remarkable how little opposition was offered, even from the beginning, to those compulsory clauses which have wrought so much for the public good. At first there was some slight protest from certain medical practitioners in the city, but this soon subsided, and the absence of any further friction speaks volumes, I think, for the care and tact with which the Health Department has been administered, and also encourages the further step of including tuberculosis among the notifiable diseases, should that course be considered necessary.

At the beginning of the period I am dealing with, the hospital accommodation for infectious disease was as follows: In Bath Lane there was a building with 24 beds, into which were admitted cases of typhoid, typhus and, to a small extent, scarlet fevers. This hospital also included a block with 24 beds for cases of smallpox, but this part of the building was closed at the end of 1882 when the Moor Smallpox Hospital was erected, a 
suspicious outbreak of the disease in Stowell Street, a densely populated locality adjoining the Bath Lane Hospital, probably hastening the closure of the smallpox wards. There was also a convalescent home at Byker for smallpox patients. Even after the opening of the Moor Smallpox Hospital, need of further hospital accommodation for fever cases was felt, the diseases which were especially prevalent being smallpox and typhus, typhoid and scarlet fevers. As regards the extent of the isolation of these diseases, there were admitted into hospital more than half the total number of smallpox cases, nearly all the typhus cases, and under one-seventh of the typhoid cases, but scarcely any attempt could be made to deal with scarlet fever.

In the latter part of 1888 the Bath Lane Hospital was closed, and the present City Hospital at Walker Gate opened, with its four large pavilions and one isolation block, the whole containing 105 beds, and from this time onwards a larger percentage of cases of scarlet and typhoid fevers was treated in hospital.

On several occasions extensions have been made to the Moor Smallpox Hospital, and at the present time the additions to the City Hospital at Walker Gate are approaching completion. Thus, in the course of this summer, Newcastle, with its estimated population of 272,969 , will have the Moor Smallpox Hospital and Isolation House, capable of accommodating 70 patients and 100 "contacts," and the hospital at Walker Gate, comprising 6 large pavilions and two isolation blocks, containing 175 beds.

Within a few years, the notification of infectious disease brought to light much useful information as to the spread of infection, and the deduction was soon made that home isolation was impossible among the working classes. Thus, in the year 1884 , it was found that 70 per cent. of the infectious disease of the city occurred in tenement property, and to encourage the sending of patients to hospital, the Sanitary Committee in this latter year authorised the free admission of all cases of infectious disease occurring in this class of property or in houses of persons in poor circumstances. In the year 1900 further facilities were offered by the Sanitary Committee for the treatment in hospital of cases of infectious disease, and all classes were admitted to the general wards free of cost, a fee still being charged for private wards. As regards the extent to which cases of diphtheria and scarlet and typhoid fevers have been isolated in hospital during the 5 years 1901-5, the average for patients in private practice was 38.4 per cent. of those notified in this class of practice, and for those notified in public practice, $72 \cdot 9$ per cent. 


\section{A Sketch of the Sanitary History of Newcastle-upon-Tyne.}

Apart from considerations of the benefit to the public health, the great advantages offered by the isolation in hospital of cases of infectious disease, both to the patients themselves and to other members of the households, who would otherwise suffer the many inconveniences associated with the treatment of an infectious case in their homes, are being more and more appreciated by the general public; and this appreciation is becoming more marked among the well-to-do classes, who are curtainly making greater use of these hospitals than in former days.

On account of the larger percentage of cases recently treated in hospital, and also on account of the extension of the city boundaries, the hospital accommodation for infectious disease in Newcastle has been strained to the utmost during the past few years, and it cannot be said that it will be excessive even when the present alditions to the City Hospital at Walker Gate lave been completed. There is nothing more liable to bring fever hospitals into disrepute than the overcrowding of such institutions, which is apt to accompany inadequate accommodation, for it is during such times that return cases, instances of cross infection, and severe complicated cases, are especially likely to occur; and probably few, except those who have had charge of such hospitals, can realise the constant anxiety that is involved in their administration under these conditions.

Turning now in detail to the several infectious diseases which have been present in the city during the last 25 years, we have ample evidence of the improvement of the public health, and this is also shown in the fall of the zymotic death-rate from an average of 3.5 per 1,000 population for the 5 years $1883-7$ to an average of $1 \cdot 5$ for the 5 years $1901-5$. The following table gives for the two quinquennia the prevalence, case mortality and death-rate of scarlet fever, typhoid fever and diphtheria respectively, and the death-rates of measles and tuberculosis.

\begin{tabular}{|c|c|c|c|c|c|c|c|c|}
\hline \multirow{2}{*}{ Disease. } & \multicolumn{2}{|c|}{$\begin{array}{c}\text { Arerage Yearly } \\
\text { Number of } \\
\text { Cages Notifled. }\end{array}$} & \multicolumn{2}{|c|}{$\begin{array}{l}\text { Avorage Yearly } \\
\text { Attack-rate per } 1,000 \\
\text { population. }\end{array}$} & \multicolumn{2}{|c|}{$\begin{array}{c}\text { Average Oase- } \\
\text { mortality rate } \\
\text { per cent. }\end{array}$} & \multicolumn{2}{|c|}{$\begin{array}{l}\text { Avorage Doath- } \\
\text { rate per } 1,000 \\
\text { population. }\end{array}$} \\
\hline & $1883-7$. & 1001-5. & $1883-7$. & $1901-5$ & $1883-7$ & $1901-5$. & 1883-7. & $1901-5$. \\
\hline $\begin{array}{l}\text { Searlet Fever .. } \\
\text { Typhoid Fever .. } \\
\text { Diphtheria .,...... } \\
\text { Mensles ............ } \\
\text { Tuberculosis ..... }\end{array}$ & $\begin{array}{r}1351 \\
251 \\
72 \\
\cdots \\
\cdots\end{array}$ & $\begin{array}{r}1107 \\
57 \\
190 \\
\ldots \\
\ldots\end{array}$ & $\begin{array}{l}8 \cdot 8 \\
1 \cdot 6 \\
0 \cdot 47 \\
\ldots \\
\ldots\end{array}$ & $\begin{array}{l}4.9 \\
0.25 \\
0.82 \\
\ldots \\
\ldots\end{array}$ & $\begin{array}{r}6.5 \\
17.9 \\
29 \cdot 4 \\
\ldots \\
\ldots\end{array}$ & $\begin{array}{r}2 \cdot 9 \\
17 \cdot 5 \\
19 \cdot 3 \\
\ldots \\
\ldots\end{array}$ & $\begin{array}{l}0 \cdot 56 \\
0 \cdot 30 \\
0 \cdot 12 \\
1 \cdot 07 \\
3 \cdot 3\end{array}$ & $\begin{array}{l}0 \cdot 15 \\
0 \cdot 04 \\
0 \cdot 15 \\
0 \cdot 27 \\
2 \cdot 5\end{array}$ \\
\hline
\end{tabular}

Average population $\quad \ldots \quad 152,232,1883-7 ; 229,370,1901-5$. 
From this table it will be seen that scarlet fever shows a marked improvement under each of the headings, and the reduction in the casemortality rate, when compared with that of typhoid fever and diphtheria, is especially noticeable. Indeed, this mildness of the clisease, and the consequent difficulty of detecting and isolating many ill-clefined cases, probably in no small degree causes its continuance amongst us.

Typhoid fever, a disease which has so often been found to vary in extent inversely with the thoroughness of the sanitary measures adopted, shows a still more marked reduction in its prevalence and death-rate. Several small outbreaks of the disease during the earlier part of the quarter-century were definitely traced to local insanitary conditions, but with the improvement of these latter and a more systematic isolation of cases in hospital, these outbreaks have practically disappeared.

The most striking anomaly shown by the infectious diseases is in connection with diphtheria. This disease, within the memory of many present, was once rare in our large towns, but it has increased within comparatively recent years in spite of sanitary improvements, hospital isolation, and the most scientific methods of treatment, until it is now one of the chief infectious diseases with which we have to deal. The more accurate means of diagnosis which are now available may to some extent account for the increase in the number of diphtheria notifications, but this is certainly only a partial explanation.

The only source of satisfaction we have in Newcastle as regards this disease is a diminished case-mortality rate, which, however, is still a high one, and contrasts unfavourably with that of London and many other southern towns. From a return prepared by Dr. Armstrong in 1904 of the case-mortality rates of diphtheria in thirty-one large towns of England and Wales, it appears that the type of the disease in the northern districts is more severe than that found farther south, the average case-mortality rate per cent. for the five years 1900-4 being for

$$
\begin{array}{rllll}
18 \text { northern towns } & \ldots & \ldots & \ldots & 24 \cdot 7 \\
5 \text { midland towns } & \ldots & \ldots & \ldots & 15 \cdot 7 \\
8 \text { southern towns } & \ldots & \ldots & \ldots & 13 \cdot 1
\end{array}
$$

Whether this difference in the severity of the clisease in the north and south can be explained entirely by the difference in the social conditions which exist in the respective districts, and which may lead to a later detection of the disease in the northern manufacturing towns and a consequent later administration of antitoxin, or whether there is a more virulent strain of the bacillus in the north, giving rise to a more severe 


\section{A Sketch of the Sanitary History of Newcastle-upon-Tyne.}

type of the disease, are points worthy of discussion. I would ask bacteriologists whether the different strains of the bacillus may not, even to a slight extent, furnish specifically different toxins, which may not necessarily be neutralised by the antitoxin in general use, this antitoxin, I am informed, being obtained in most laboratories by immunisation with the toxins of a special strain of bacillus, which was imported from another country. In favour of the latter view, I may add that at the City Hospital here, where antitoxin in doses of from 6,000 to 12,000 units is given as a routine treatment, Dr. Harris and myself have not had evidence that antitoxin is the definite curative agent which it has apparently proved itself to be in the hospitals of the Metropolitan Asylums Board. There is, howcver, this fallacy as regards diphtheria statistics, that at least one southern town includes amongst its cases of diphtheria those "contacts" in whose throats the bacillus is found, but who do not show any clinical symptoms of the disease.

Typhus fever, except for a few sporadic cases, has been absent from Newcastle since 1891, its last appearance in the city being in 1903, when there were three cases, all of which recovered. The history of the last fifteen years differs therefore very markedly in this respect from the records of more remote times, when so prevalent was the disease and so infectious to those brought into close contact with it, that between 1865 and 1872, thirty-one officials at the Fever Hospital contracted the disease, and five of these died. It was on this account the usual practice in those days as far as possible to fill up vacaucies among the nursing staff from former female patients who had recovered from the disease. Between 1873 and 1887 typhus fever made its appearance no less than fourteen times, but was each time successfully stamped out.

Smallpox was raging in the city during the first four years of our period. Since then there has been no large outbreak until 1903, when an epidemic began and continued until the middle of 1905, giving rise to 614 cases, and showing a case mortality rate of 4.5 per cent. $(2 \cdot 9$ per cent. for vaccinated cases and 10.4 per cent. for the unvaccinated). During this epidemic practically all direct contacts, 2,551 in number, were removed to the Moor Isolation Hospital, adjoining the Smallpox Hospital, where they were retained for from twelve to seventeen days, and cluring this time compensation was paid to them for actual loss of wages, etc. $3 \cdot 4$ per cent. of these contacts developed smallpox in the Isolation Hospital, and thus the city was saved from the infection of these 86 cases.

Measles, although more or less prevalent during the whole period; 
shows a reduced average death-rate per 1,000 population of $\cdot 27$ during the recent years, as compared with 1.07 during the earlier years. A very instructive experiment was made from August, 1896, to August, 1898, measles and whooping cough being included amongst the notifiable diseases, and 7,680 cases of measles and 3,746 cases of whooping cough were notified, at a total cost of $£ 1,881$. In spite of energetic action on the part of the Health Department on receipt of the notifications and the occasional closure of schools, the medical officer of health had to report at the end of two years that "the outcome of notification had certainly not been a general reduction of these diseases," and expressed his opinion that, with respect to measles, the most practical means of preventing large epidemics was to be found in the prompt closure of every school in which the disease should appear.

As regards the several forms of tuberculosis, for the prevention of which disease so little has hitherto been specially attempted, we have nevertheless a steady, even though it may not be a very marked, reduction in the death-rate, for the table shows an average tuberculosis deathrate of $3 \cdot 3$ per 1,000 population in the early quinquennium as compared with one of 2.5 per 1,000 for the recent period. That the more energetic dealing with this disease is becoming one of the chief hygienic questions of the day, that there is much which both can and will be done to diminish this scourge, there can be little cloubt. Dr. Armstrong's firm stand in condemning as unfit for food the whole of any tuberculous carcase, despite the butchers' protests that "parts only are affected," has protected Newcastle from this source of infection so far as the difficulty of supervising its many slaughter-houses has permitted. Towards the end of last year, the bacteriological examination of the various milk supplies for the tubercle bacillus was begun, and when adequate legal powers have been obtained for allowing the necessary action to be taken after the detection of the bacilli, another fruitful source of infection will, it is hoped, be cut off. A sanatorium for the treatment of tuberculosis in its initial stages has lately been erected at Barrasford, and the Corporation of Newcastle are considering a contribution to the institution and an arrangenent which will enable them to have twenty beds at their disposal.

Recently a special report on tuberculosis, giving a very comprehensive survey of the measures necessary for the thorough dealing with the disease, has been submitted to the Sanitary Committee by Dr. Armstrong.

Having thus briefly referred to the chief infectious diseases which have been prevalent in the city during the 25 years, I will now turn to another 


\section{A Sketch of the Sanitary History of Newcastle-upon-Tyne.}

question of great moment, that of infantile mortality. In this respect Newcastle has held a middle position among the large towns, and can show a moderate improvement, the average rate for the five years 1883-7 being 165 per 1,000 births registered, and that for the five years 1901-5 being 155. Since 1901 six health risitors have been appointed, and through them, working in conjunction with the superintendent of midwives lately engaged to assist in the working of the Midwives Act, it is hoped to further reduce the infantile death-rate. Recently the Corporation has offered a fee of 1 s. to all midwives notifying within 24 hours the birth of any living child in their practice, and these infants are visited within the first week of birth by the superintendent of midwives, and afterwards at certain intervals during the first twelve months by the health visitors. By the instruction given to mothers by these ladies as to the hygiene of the home and the care of the infant, and by means of the distribution of printed pamphlets on infant feeding, a crusade is being carried on against this loss of infant life. The recently instituted routine bacteriological examination of the city's milk supply cannot but disclose many a danger to which the infant has been hitherto exposed.

Closely associated with this subject of infantile mortality is the work recently undertaken in connection with the Midwives Act, and the utmost importance of this Act, both in giving the health authorities control over the midwives, and also in indirectly affording them opportunities of coming into closer contact with mothers and their young offspring, is becoming most evident. Thus, the superintendent of midwives not only supervises that part of the midwires' work which concerns the mother's welfare, but also encourages the midwives and the mother's to take an intelligent interest in the care of the child. Circumstances which have a bearing on the inability of the mother to suckle her child are especially inquired into, and as far as possible rectified, and in this way the child begins existence under conditions which are at any rate less directly hostile to its survival than those which have hitherto of ten attended its early days. The compulsory notification by certified midwives of still-births attended by them, and the obtaining of information from the superintendents of cemeteries of all burials of still-born children in the city, enable the health department to investigate the circumstances of each case, and thus not only is a check exercised over any criminal practice, but also opportunity is given for ascertaining and dealing with any maternal conditions which may have led up to the death of the fotus. The extent of puerperal fever in the city during the quarter century is with difficulty arrived at, for many cases 
remain unnotified, but the returns of cases notified show a definite reduction in its prevalence from an average of 11.6 cases per year for the early five years to an average of 4 per year for the recent five years.

There is no more striking feature of the sanilary administration of recent times than the daily practical use to which the science of bacteriology lias been put. In the year 1898, the Corporation of Newcastle first instituted a routine bacteriological examination of its water supply, and since 1905, examinations for the diagnosis of tuberculosis, diphtheria and enteric fever have been carried out by the Corporation free of cost for medical practitioners in the city. Last year an arrangement was made with the Durham College of Medicine whereby the Corporation have a far more extended use of the College's bacteorological department, and the routine examination of samples of milk for tubercle bacilli and for organisms associated with dirt was also begun. For the present, valuable information is thus being collected as to the bacterial condition of the various milk supplies, the tubercle-containing milk is traced back to the clairy farm and excluded from the city, and an attempt is mide to remedy any insanitary conditions in connection with the procluction and storage of milk found to contain a large number of organisms indicating the admission of dirt.

That these sanitary measures have borne good fruit in the way of an improved public health is far too evident to require the confirmation afforded by the statistics contained in this paper, and Newcastle of to-day can show a record of sanitary progress of which any city might be proud, and one in which its city fathers and medical officer of health may take no little satisfaction.

VOL. SXVIII. NO. 4. 


\section{W. H. WELLS.}

I PURPOSE dealing as briefly as possible with that portion of the 1 paper on "Sanitary Progress in Newcastle-upon-Tyne during the last Twenty-five years," which has been allotted to me, hecause it can, for the most part, be expressed only statistically.

During the interval embraced by the paper the area of the city has been enlarged by the addition of Benwell, Fenham, and Walker. These districts were previously each governed by an urban district council. Statistics, therefore, are more complicated than if the area of the city had remained the same throughout the whole period under review.

\section{Area ind Population.}

The area of the city in 1882 was 5,371 acres, and the population about 147,000. This gives a rate of 27 persons to the acre. Just previous to the extension above referred to the population was 225,362 , or a rate of 42 persons per acre, including the Town Moor and the Leazes.

Benwell, Fenhan, and Walker, with an almost unpopulated portion of Kenton, were added to the city in November, 1904. They contain 3,088 acres. The acreage of the city to-day, therefore, is 8,459 , and the total population, including these added areas, was, in 1905, 264,511; rate of persons to the acre, 31 .

\section{Rateable Value.}

The rateable value in 1882 was $£ 739,754$. According to the last assessment it is now $£ 1,640,873, £ 148,600$ of which is due to the added areas. During the last fifteen or perhaps twenty years, an enormous amount of money has been spent by owners of property in some of the principal streets of the city, in pulling down old houses and erecting new and costly buildings in their stead. One such building, the largest, has cost, in the purchase of old houses and the building of the new, over a quarter of a million pounds sterling. In other streets tenemented houses in large numbers have been removed to make room for the erection of business premises, and for railway extensions. Many old houses have been closed as unfit by the sanitary authority. Against this, about 24,300 dwelling-houses have been built during the last twenty-five years, a large proportion of which are in flats, ranging in rent from 4s. to 11s. per week. The Corporation has also erected houses for the working classes to accom- 
modate 204 families. For the closure of houses unfit, this authority cloes not proceed under the Housing of the Working-classes Act, which is cumbersome and often abortive, as two men, as magistrates, may stultify: the action of seventy-six as councillors, a power which has been frequently exercised. The power now used by the Council is one obtained in a Local Act, and which enables the authority to close houses which are unfit, on the certificates of the Medical Officer of Health, and without the necessity of having recourse to the Court of Summary Jurisdiction, except for the infliction of penalties when their closing order is not complied with, the magistrates having no power to go behind that order.

In 1885 there were 138 miles of streets. Now there are 233, including the added areas.

At the commencement of the period under review, all the streets (excluding the main roads), excepting a few which are very steep, were paved with granite setts. During the last few years, several of the principal streets have been repaved with wood, and, at present, tar macadam is laicl, and is being laid, instead of the setts, in many other streets.

The staff for strect scavenging and removal of house refuse consists of 585 men and 77 horses.

43 miles of streets are watered during dry weather, some continuously, some twice, and some three times a day.

\section{SEwERS.}

There are 201 miles of sewers, mostly in back streets. To this number must be added 56 miles of chrains intended for surface water only. The sewage of Gosforth also passes through the city. The whole of the sewage, both of this city and Gosforth, is discharged into the River Tyne, without treatment.

\section{Sanitary Convenievces.}

As to sanitary conveniences, I can only obtain information back to 1887. The numbers in that year, and in 1905 , were as follows :-

$\begin{array}{llrr} & & 1887 . & 190 \overline{5} \\ \text { Water-closets } & \ldots & 18,055 & 43,348 \\ \text { Privy-pails ... } & \ldots & 2,362 & 5,913 \\ \text { Privy-ashpits } & \ldots & 6,360 & 960^{*} \\ \text { Ashtubs } \ldots & \ldots & 1,047 & 32,774 \\ \text { Dry ashpits ... } & \ldots & 11,337 & 2, \bar{p} 63\end{array}$

* Ashpits with privies and privy boxes in Walker and Benwell. 
These figures shew an enormous decrease in the number of privyashpits and an increase in the number of water-closets, also a noticeable increase of privy-pails. These very offensive things were permitted by the authority until a few years ago, in substitution for privies and ashpits removed, but now they are not allowed to be made, water-closets being the only conveniences of the kind sanctioned.

The dry house refuse is remored from every house twice a week, in the daytime; the contents of privy-pails three times a week in the night-time.

The authority has of recent years taken such action in the abolition of privy-ashpits that there are now none left west of the Ouseburn, excepting, perhaps, half-a-dozen which belong to houses in the suburbs having large gardens.

\section{Street IJighting.}

Ten years ago there were 5,656 gas and 24 electric lamps; the cost of burning was $£ 14,484$, giving an illuminating power of 126,496 candles. To-day we have 8,033 gas and 737 electric lamps, giving an illuminating power of $1,046,370$ candles, and costing $£ 28,186$ per annum.

It may be interesting to record, as another indication of the growth of the district (including, of course, Gateshead and the other towns in the gas company's area), and of the extended use of gas for power and for domestic use, both having a distinct influence on the smoke nuisance question, that the gas made by the Newcastle \& Gateshead Gis Co. was, in $1882,1,143,048,000 \mathrm{c} . \mathrm{ft}$., and in $19053,254,383,000 \mathrm{c}$. ft., an increase of $2,111,335,000$ ), or $184 \frac{3}{4}$ per cent. The number of gas cookers in the company's area in 1882 was about 300 ; on the 31st December, 1905 , there were 43,256 lent on hire by the company, and about 1,500 owned by consumers, making a total of 44,756. Of gas fires, 1,917 were supplied by the company up to the end of 1905 , and probably a much larger number was in use supplied by the local plumbers and ironmongers. The number of gas engines in use in 1882 was probably 200 ; in 1905 it was (885. When to this large number is added that of engines whose motive power is electricity, the number of which is not known to the writer, it will be seen that the amount of smoke made must have been considerably lessened.

\section{Trans.}

In 1882 the tram lines of the city were being worked by a company, to whom they were leased by the Corporation, the company using hurses for traction. In April, 1901, the lease terminated. The local authority 
laid down new lines and provided an electric tram system, which was opened in December, 1901. There are now $52 \frac{1}{2}$ miles of line, and 105 cars running on ordinary weeklays, and 145 on Saturdays. The cost of the system was about $£ 1,154,099$.

\section{Parks and Open Spaces.}

The area of public parks and grounds remains nearly the same as in 1882. The Nun's Moor Park has been formed since that date, hut upon ground which was previously public. The Cruddas Recreation Ground, four acres, has been added. The parks and recreation grounls of the added areas cover 28 acres. The total acreage now, including the Town Moor and Castle Leazes, is 1,284 acres (3 roods 18 poles), that of cemeteries and churchyards, 104 acres, of private grounds and open spaces, 37 acres, making a total, with the odd roods and poles, of 1,427 acres, 1 rood, 33 poles.

\section{Baths AND Washhouses.}

In 1882 there were three sets of baths in the city, owned by the Corporation, but leased to private individuals, the Northumberland, Gallowgate, and City Road baths. These have since been taken over and worked by the Authority. In 1884 the new baths at Elswick, Byker, and Westgate, were opened to the public, and in that year the total numbers of bathers were: private baths, 81,347; Turkish, 7,125; swimming, 85,696 . The numbers of bathers last year were: private baths, 90,302 ; Turkish, 4,746; swimming, 162,636. In addition to this, about 121,000 persons used the washhouses. Last year the Education Committee made arrangements with the Baths Committee to admit scholars from the elementary schools free of charge during school hours, the scholars to be taught the art of swimming. As a result of this agreement, last summer 32,233 boys, and 7,077 girls were admitted to the baths.

\section{Adulteration Acts.}

In 1882 the number of samples of food and drugs submitted for analysis was 102 ; in 1905,597 samples were purchased for this purpose. The somewhat large number of samples we submit for analysis is taken with the minimum expenditure of time and money. All (save milk) are purchased informally, and with the aid of hired help. Thus the long time required for division, etc., is saved, the quantity purchased is only one third of that which would be required if the sample were divided, and, better than all, no retailer is aware that he is selling to an inspector for analysis. 


\section{He.te'th Departinent Stafr.}

In 1882 the staff consisted of the medical officer of health, a chief inspector of nuisances, four assistant inspectors, a chief inspector of provisions and onc assistant, and two clerks, ten in all. To-day its composition is : medical officer of health, assistant medical officer of health, chief inspector of nuisances, assistant chief inspector, nineteen assistant inspectors, one chief inspector of provisions and two assistants, six health visitors, a superintendent of midwives, and six clerks, thirty-nine in all, besides the staffs of the lospitals.

\section{Common Lodging Houses.}

In 1892 the inspection of common lodging houses, which had until then been in the liands of the police, was placed with the health department. At that time the greater number of these houses were old dilapidated places in slum districts. By constant effort, almost unsupported by help? from the law, nearly the whole of these, certainly the worst of them, have ceased to be used as common lodging houses. Great care has beel exercised that other houses proposed for registration were suitable for the purpose. The double beds, with which all the houses were fitted up, have been removed, and single beds provided instead.

\section{Drains of New Houses.}

The inspection of drains, soil-pipes, etc., of new houses has been given to the Health Department, three officers being appointed for that work. This is a good arrangement, because, by it, the sanitary inspector, who is afterwards, in a sense, responsible for the maintenance of good Irainage of houses, hils an opportunity of making sure that they are right at the start.

\section{WORKSHOPS, E'TC.}

Since 1901, two officers of the staff have been set apart for the cxamination of workshops, \&c. At the present moment we have upon our register:-886 workshops, 104 domestic workshops, 92 workplaces, 58 laundries, 104 bakehouses, a total of 1,244.

This record of the sanitary progress of Newcastle is not, of course, fully comprehensive, but curtailed as much as possible in order to lessen the monotony of figures, yet presents such a view as may convey a general impression of the truth. 
Councillon R. Flowers (Newcastle-on-Tyne) emphasised the necessity of providing for the poor people opportunities for getting light and pure air. The sanitary authority had applied themselves to the erection of houses for the labouring classes, with rooms light and airy, and with well-rentilated conveniences. At no distant date, a garden city would be springing up on the Walker estate. He had never heard anybody grumble at the amount of money spent in preventing the spread of disease and in seeking to guard the health of the people.

Couscillor Dr. Trplain (Newcastle-on-Tyne) said the progress during the past twenty-five years had been great, but the future had in store still greater elements of success for Newcastle. He complimented Dr. Armstrong and the health visitors very lighly. They had done much. He knew that the health risitors were doing a grand work, and the results would be great in future years. The death-rate was decreasing, and soon they hoped for greater improvement, and that in the near future there might be more control of disease, and twenty years or more added to the average human life. The infintile mortality was also decreasing, but it was still far too high. Here, too, they had great hopes, for 'ducational processes were at work which must result in improvement all along the line. The housing question was an urgent one, and they needed to build for the poor with small incomes. The houses so built should be built for the present generation, not to last for ages.

Dr. H. E. Ararstroxt (Newcastle-on-Tyne) said the Corporation of Newcastle had done a great deal in recent years to inprove tenemented property, and there were now rery few of the old slums that he lnew in his young days. At present the rents required from the poorer classes of people were very much above what they could afford. Building regulations, which would give more space and less thickness of walls, so that rents should not be increased by unnecessary brickwork, were wanted, he urged. 